\title{
Effect of manipulative treatment in patients with mechanical neck pain: a systematic review
}

\author{
Jossandra Cássia de Maria Alves Teles,3, Daniel Nunes de Oliveira',3, Antônia Vitória Silva Mota ${ }^{1,3}$, \\ Patrícia Xavier Lima Gomes²,3, Francisco Fleury Uchôa Santos-Júnior',2,3.
}

\begin{abstract}
Introduction: The neck pain especially of mechanical origin (related to the joints of the spine) interfere in health and quality of life of individual widely affecting the population. Objective: Analyze through a systematic review the effectiveness of manipulation as a therapeutic tool in neck pain. Method: The search was performed using the following databases: Scientific Electronic Library Online (SCIELO), Virtual Health Library (BIREME), PubMed (MEDLINE) and Google Scholar with the descriptors "Cervical manipulation", as well as associated with the word "joint", in the last 14 years (2001 to 2015). The search resulted in 446 articles of which 49 were selected for reading the full text, but only 10 articles contemplated the methodological criteria. There were included studies that approach about the neck pain, using manipulation associated with physiotherapy techniques. Reviews, master and doctoral thesis and Completion of Course Work were excluded, as well as studies involving animals. Results: The articles included in this study were submitted to methodological quality analysis of the PEDro scale, in which all items have average higher than or equal to six. The sample size ranges from 6 to 96 subjects with age between 18 and 65 years old. Regarding the gender of patients the prevalence was $35.71 \%$ for males and $64.28 \%$ for females, being this one predominant in the studies included in the research. The majority of the evaluated articles proved to be favorable to cervical manipulation with improvement of pain in $48.9 \%$ of patients in primary care and about $75 \%$ decreased in 6 months, as well as improvement of functional limitation. Conclusions: The cervical manipulation proved to be an important and effective technique in the treatment of mechanical neck pain, because it can minimize the painful condition and restore range of motion.
\end{abstract}

Keywords: Spinal manipulation, Physiotherapy, Osteopathic Medicine.

\section{INTRODUCTION}

Neck pain is a musculoskeletal problem that compromises the health, the quality of life of individuals ${ }^{(1)}$ and widely affects the population and can be acute or chronic. According to the World Health Organization (WHO), $50 \%$ of adults suffer from neck pain at some point in their lives. ${ }^{(2)}$ Among the most common conditions fit the whiplash injury, cervical muscle spasm, dysfunctions with impairment of the upper limbs and mechanical derangements. ${ }^{(3)}$

The origin of neck pain is multifactorial and may be related to repetitive movements, lack of breaks at work, static jobs keeping the head and/or arms in the same position for too long. ${ }^{(4-5)}$ Regarding the clinical features of the patients, they can report pain associated or not to a strength deficit in the flexor and extensor muscles of the cervical region, ${ }^{(6)}$ limited range of motion and increase in muscle fatigability. ${ }^{(7)}$ Neck pain can be related to sudden or abrupt movements, long stay in a forced position, stress or trauma, and can be defined as a pain on the back of the neck and upper shoulder blade or upper dorsal, which is not accompanied by characteristic signs of the radiculopathy. ${ }^{(8,9,10)}$

One of the neck pain treatment ways is through techniques related to physiotherapy, for example: in cases of mechanical neck pain, the Positional Release Therapy (PRT), which aims at the harmonization of the musculoskeletal system, approaching passively origin and muscle insertion with specific placement of body segments, with the finality of reduce the pain, normalize the myofascial tension, relax the periarticular tissues and improve the circulation. ${ }^{(11)}$ Therefore, manipulation of the spine can be set as a manual application technique of a physical impulse performed in a short period of time, that is, high speed and low amplitude. These movements and applied forces are generated to cause vertebral displacement within physiological limits of movement modifying the local stress. ${ }^{12)}$ The objective of the present study is to analyze the effectiveness of manipulation as a therapeutic tool in neck pain. 


\section{METHOD}

\section{Eligibility Criteria}

The study included articles that approached manipulation of the cervical spine with the use of high speed and low amplitude techniques related to range of motion disorders. In this study were excluded clinical trials that did not report diseases involving cervical joint, the ones that had absence of clinical trials randomized without amounts of group of participants, as well as reviews, master and doctoral thesis, completion of course work and studies involving animals.

\section{Search strategy and selection of the study}

The search was performed using the following electronic databases in the last 14 years (2001 to 2015): Scientific Electronic Library Online (SCIELO), Virtual Health Library (BIREME), PubMed (MEDLINE) and Google Scholar. The researches were realized between March and May 2015 and comprehend the following descriptors: "Cervical manipulation" isolated or associated with the word joint. The articles were repossessed in English and Portuguese.

\section{Data extraction}

Initially in Figure 1, by placing the descriptors in the databases were found 446 articles, in which: Scientific Electronic Library Online (SCIELO) with $n=274$; PubMed (MEDLINE) with $n=21$; LILACS with $n=19$; Virtual Health Library (BIREME) with $n=26$; Google Scholar with $n=106$. Shortly after a thorough reading of the abstracts of the studies, 436 were excluded because they did not include the established methodological criteria. In total were read 10 papers in full. The overall quality of the articles was analyzed according to the evaluation items of the Physiotherapy Evidence Database-PEDro scale.
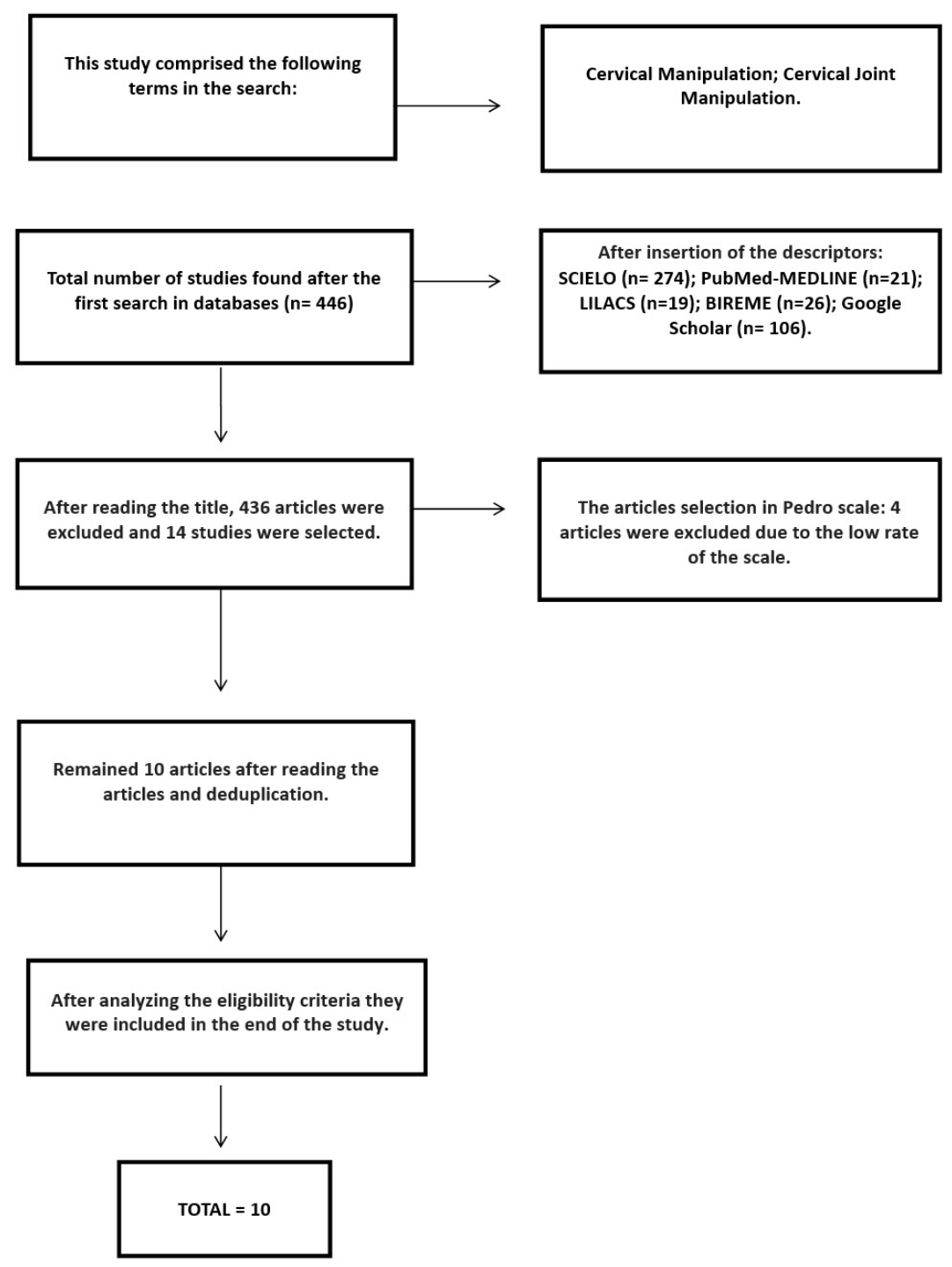

The articles selection in Pedro scale: 4 articles were excluded due to the low rate of the scale.

Figure 1. Flowchart of the studies included in the research. 
This scale has 11 items for assessment of PEDro table and for better classification of articles was applied specific result, according to the table criteria. Each satisfied item (except the first) contributes one point to the total score of the scale. The final score is obtained by the sum of all positive responses, and those that have average equal or higher than five on the scale were considered of high methodological quality.

Following are described the aspects analyzed by PEDro table as criteria to be followed to evaluate the studies. 1. The eligibility criteria were specified. 2 . The subjects were randomly allocated to groups (a crossover study, the subjects were placed randomly into groups according to the treatment received). 3. The allocation of subjects was secret. 4. Initially, the groups were similar in regard to most important prognostic indicators. 5. All subjects participated in the study blindly. 6 . The therapy was administered blindly by all therapists. 7. All assessors who measured at least one key outcome did it blindly. 8. Measurements of at least one key outcome were obtained in more than $85 \%$ of the subjects initially distributed between the groups. 9. All subjects who presented measurements of results received the treatment or control condition as allocated, or when this was not the case, the analysis was made for at least one of the key outcome by "intent treatment". 10. The results of statistical comparisons intergroup were described for at least one key outcome. 11. The study presents both precision measures as variability measures for at least one key outcome.

\section{RESULTS}

The table 1 presents the main data as author and year, objective of the study, intervention, results and outcome. The sample size ranges from 6 to 96 subjects with age between 18 and 65 years old. Regarding the gender of patients the prevalence was $35.71 \%$ for males and $64.28 \%$ for females, being this one predominant in the studies included in the research.

In Table 2 contains information about methodological quality using the PEDro scale, which can be evidenced that all the items included in this study underwent this legitimacy, and according to the classification all of them had average higher or equal to six, in which $33.3 \%$ of these score six, $41.62 \%$ score seven and $24.97 \%$ score eight. Therefore, all items had a good methodological quality.

Table 1. Main characteristics of the studies as author and year of the article, objectives, intervention, results and outcome.

\begin{tabular}{|c|c|c|c|c|}
\hline Author/year & Objective & Intervention & Results & Outcome \\
\hline Kamonsekiet al 2012 [13] & $\begin{array}{l}\text { Determine the immediate } \\
\text { influence of high-velocity } \\
\text { low-amplitude technique } \\
\text { (HVLA) applied to the upper } \\
\text { cervical spine in active mouth } \\
\text { opening. }\end{array}$ & $\begin{array}{l}\text { High-velocity low-amplitude } \\
\text { technique (HVLA). }\end{array}$ & $\begin{array}{l}\text { In intragroup analysis: } \\
\text { there were no significant } \\
\text { differences from the control } \\
\text { group. In experimental } \\
\text { group: amplitude of mouth } \\
\text { opening was significantly } \\
\text { higher post-intervention when } \\
\text { compared to pre-intervention } \\
\text { time. }\end{array}$ & $\begin{array}{l}\text { This study showed that } \\
\text { HVLA applied in the upper } \\
\text { cervical region promoted } \\
\text { immediate improvement } \\
\text { in mouth opening, because } \\
\text { the range was greater after } \\
\text { performing the technique } \\
\text { in the experimental group } \\
\text { compared to the control } \\
\text { group. }\end{array}$ \\
\hline Barbosa et al 2012 [14] & $\begin{array}{l}\text { Check the effectiveness of } \\
\text { spinal manipulation by full- } \\
\text { scanning technique in the } \\
\text { correction of head protrusion } \\
\text { and the relief of neck pain } \\
\text { and headaches, as well as the } \\
\text { electrical activity of the upper } \\
\text { trapezius muscle before and } \\
\text { after the protocol. }\end{array}$ & Full-scanning technique & $\begin{array}{l}\text { Pain analysis: the ten patients } \\
\text { who completed treatment } \\
\text { achieved significant results in } \\
\text { pain analysis in the studied } \\
\text { groups, with a group with very } \\
\text { significant results. } \\
\text { The biophotogrammetry } \\
\text { analysis has indicated } \\
\text { significant differences in the } \\
\text { groups. }\end{array}$ & $\begin{array}{l}\text { The results suggest that the } \\
\text { full-scanning technique was } \\
\text { relevant to pain reduction } \\
\text { between the initial and } \\
\text { final moments as well as for } \\
\text { angular reduction occurred } \\
\text { in biophotogrametrics } \\
\text { data, with consequent } \\
\text { improvement of cervical } \\
\text { and head positioning of the } \\
\text { studied volunteers. }\end{array}$ \\
\hline Stelleet al 2013 [15] & $\begin{array}{l}\text { Check if the osteopathic } \\
\text { manipulation through } \\
\text { the rhythmic articulatory } \\
\text { technique generates increase } \\
\text { of cervical rotation amplitude } \\
\text { measured by fleximetry. }\end{array}$ & $\begin{array}{l}\text { Osteopathic manipulation } \\
\text { with the cervical rhythmic } \\
\text { articulatory technique. }\end{array}$ & $\begin{array}{l}\text { There was a significant } \\
\text { increase of range of motion in } \\
\text { all cases. }\end{array}$ & $\begin{array}{l}\text { There was a significant } \\
\text { increase of range of motion } \\
\text { in all cases. The OM-CRAT } \\
\text { (Osteopathic Manipulation } \\
\text { with Cervical Rhythmic } \\
\text { Articulatory Technique), } \\
\text { proved to be effective in } \\
\text { cervical rotation amplitude } \\
\text { gain and may serve as a } \\
\text { treatment for diseases that } \\
\text { are related to vertebral } \\
\text { hypomotility, as neck pain } \\
\text { and cervical osteoarthritis. }\end{array}$ \\
\hline
\end{tabular}


Table 1. Continued...

\begin{tabular}{|c|c|}
\hline Author/year & Objective \\
\hline Stelleet al 2014 [16] & $\begin{array}{l}\text { Check if osteopathic } \\
\text { manipulation with cervical } \\
\text { rhythmic articulatory } \\
\text { technique generates abnormal } \\
\text { oscillations of the blood } \\
\text { flow velocity or risks to the } \\
\text { circulation of the internal, } \\
\text { vertebral, basilar and carotid } \\
\text { arteries. }\end{array}$ \\
\hline
\end{tabular}

Camargo et al 2012 [17]
Leaveret al 2010 [18]

Vargas et al 2014 [19]

Gong 2013 [20]

Hernandez et al 2012 [21] Examine the effects of Kinesio taping against cervical spine manipulation in pain neck intensity, disability and cervical range of motion in patients with mechanical neck pain.
Investigate the real-time feedback effect on the performance of CSM (cervical spine manipulation).
Identify the effects of cervical joint manipulation at the joint position sense (JPS) of norma adults.
Determine the immediate effects of C5/C6 (Ashmore) manipulation technique on the bilateral EMG activity of the middle deltoid muscle during resting and contractions.

Ashmore technique

Determining whether neck manipulation or mobilization is most effective for pain. amplitude impulse
Cervical rhythmic articulatory technique.

Technique of high speed manual therapy, lowtechniques.

Technique of low-speed manual therapy, passive oscillating movement.

Cervical spine Manipulation Technique (CSMT).
Cervical joint manipulation at the joint position sense (JPS).

Manipulative technique of high-speed and low-amplitude.

\section{Kinesio}

Taping.
Results

It is possible to say that OM-CRAT in sliding and in rotation generated no risk to the movement of the arteries, osteopathic manipulative treatment or vertebra manipulation did not cause injury or undue stress on the vertebral and carotid arteries. There was only a discrete increase of the flow velocity in the intracranial arteries after OM-CRAT.

Cervical manipulation to C5/C6 level with rotation to the left in the sitting position was able to change the behavior of muscle activity during contractions of 30 " in patients with neck pain. These changes were of a reduced size effect and was lacking uniformity with regard to the periods of beginning and end of the contraction.

There were no statistically significant differences between groups of manipulation and mobilization in the secondary outcomes of pain, disability, function, global perceived effect or health-related quality of life at any point of time.

There were significant differences in angular velocity of rotation. The results also showed no significant difference in pre-manipulator position, impulse displacement or lateral flexion of angular velocity.

Test group results revealed statistically significant differences in flexion and extension, but the control group showed no significant differences in any of the variables.

Patients who received impulse manipulation experienced a greater increase in the cervical motion rotation range than those who received the application kinesio tape.
The Ashmore C5-C6 technique reduced significantly the bilateral EMG activity of middle deltoids for 30" of isometric contraction, increasing muscle recruitment and fatigue resistance compared with the electrical activity in the control group subjects.

Nearly half of the participants of the study did not fully recovered from the episode of neck pain, however there has been rapid and significant improvement in pain scores in both groups.

Suggest that the feeding in real-time feedback derived from an inertia sensor can be used for key-variable amounts associated with the important CSM and can assist in the development of impulse speed.

Combined of massage and cervical joint manipulation is more effective in increasing the range of motion.

Patients with mechanical neck pain receiving a cervical impulse manipulation or a KinesioTaping application showed reduction in neck pain and disability and changes in cervical range of motion over a period of 7 days. 
Table 1. Continued...

\begin{tabular}{|c|c|c|c|c|}
\hline Author/year & Objective & Intervention & Results & Outcome \\
\hline Puenteduraet al 2011 [22] & $\begin{array}{l}\text { The differences in the result of } \\
\text { cervical thrust manipulation } \\
\text { compared to chest thrust } \\
\text { manipulation to treat patients } \\
\text { with cervical pain showed that } \\
\text { the treatment of the thoracic } \\
\text { spine demonstrated benefits } \\
\text { and involves less risk. }\end{array}$ & Thrust manipulation & $\begin{array}{l}\text { The study shows that patients } \\
\text { with mechanical neck pain in } \\
\text { the cervical group compared } \\
\text { with the thoracic group } \\
\text { showed significant and greater } \\
\text { improvement in all outcome } \\
\text { measures. }\end{array}$ & $\begin{array}{l}\text { It was found that patients } \\
\text { who were treated with a } \\
\text { combination of cervical spine } \\
\text { manipulation and exercises } \\
\text { showed significantly greater } \\
\text { improvement in pain and } \\
\text { disability compared to those } \\
\text { treated with thoracic spine } \\
\text { manipulation and exercises. }\end{array}$ \\
\hline Kolberg et al 2015 [23] & $\begin{array}{l}\text { The aim of this study was to } \\
\text { investigate the parameters } \\
\text { of oxidative stress in patients } \\
\text { with chronic neck pain or } \\
\text { back pain after } 5 \text { weeks } \\
\text { of treatment with high- } \\
\text { speed and low-amplitude } \\
\text { manipulation (HVLA) of the } \\
\text { spine. }\end{array}$ & $\begin{array}{l}\text { High-velocity low-amplitude } \\
\text { manipulation (HVLA). }\end{array}$ & $\begin{array}{l}\text { The study showed treatment } \\
\text { by spine manipulation twice a } \\
\text { week for } 5 \text { weeks. In subjects } \\
\text { with unspecific chronic neck } \\
\text { pain increased SOD and GPx } \\
\text { activities, without significant } \\
\text { changes. And metabolites } \\
\text { activity in systemic blood were } \\
\text { almost unchanged after } 6 \\
\text { sessions of HVLA manipulation } \\
\text { in men with neck pain. }\end{array}$ & $\begin{array}{l}\text { This study showed that SOD } \\
\text { and GPx activity in patients } \\
\text { with nonspecific cervical } \\
\text { chronic pain or back pain } \\
\text { increased after } 10 \text { sessions } \\
\text { of HVLA manipulation of the } \\
\text { spine. This study supported } \\
\text { the hypothesis that the } \\
\text { effects of HVLA manipulation } \\
\text { of the spine on the oxidative } \\
\text { stress depend on the } \\
\text { time and the frequency of } \\
\text { treatment. }\end{array}$ \\
\hline Hurwitzet al 2002 [24] & $\begin{array}{l}\text { To evaluate the relative } \\
\text { efficacy of approaches of } \\
\text { treating pain in the neck } \\
\text { approaches commonly used } \\
\text { by chiropractors. }\end{array}$ & $\begin{array}{l}\text { High-Velocity Low- } \\
\text { Amplitude manipulation. } \\
\text { Stretching, flexibility or } \\
\text { strengthening exercises } \\
\text { and advice on ergonomics } \\
\text { and modifications in the } \\
\text { workplace. }\end{array}$ & $\begin{array}{l}\text { Manipulation and mobilization } \\
\text { with or without heat, with } \\
\text { or without electrical muscle } \\
\text { stimulation produced similar } \\
\text { improvements in the intensity } \\
\text { of pain and disability after } 6 \\
\text { months. }\end{array}$ & $\begin{array}{l}\text { The results suggest that } \\
\text { cervical mobilization of } \\
\text { the spine is as effective as } \\
\text { manipulation in reducing } \\
\text { neck pain and disability } \\
\text { among patients of } \\
\text { chiropractic. Furthermore, } \\
\text { was showed that no heat or } \\
\text { electrical muscle stimulation, } \\
\text { alone or in combination with } \\
\text { manipulation or mobilization, } \\
\text { significantly improves the } \\
\text { clinical results, although } \\
\text { heat may provide short-term } \\
\text { benefits for some patients. }\end{array}$ \\
\hline
\end{tabular}

Table 2. Analysis of the articles according to the Physiotherapy Evidence Database - PEDro table scores.

\begin{tabular}{|c|c|c|c|}
\hline Study Criteria & 1234567891011 & Total quality & Methodological quality \\
\hline Kamonseki et al 2012 [13] & +++++-++-- & $6 / 11$ & High \\
\hline Barbosa et al 2012 [14] & ++++-+-+++ & $7 / 11$ & High \\
\hline Stelleet et al 2013 [15] & +--+++-+-++ & $7 / 11$ & High \\
\hline Stelleet al 2014 [16] & +-+-++-+--+ & $6 / 11$ & High \\
\hline Camargo et al, 2012 [17] & ++++-++-+-+ & $8 / 11$ & High \\
\hline Leaver et al, 2010 [18] & ++++-++-+-+ & $8 / 11$ & High \\
\hline Vargas; Williams. 2014 [19] & +-+-++-+-++ & $6 / 11$ & High \\
\hline Wontae Gong, 2013 [20] & +-+-++-+-++ & $7 / 11$ & High \\
\hline Hernández et al 2013 [21] & -+-+++-+-+- & $6 / 11$ & High \\
\hline Kolberg et al 2015 [22] & +++---++++ & $7 / 11$ & High \\
\hline
\end{tabular}

Of the articles analyzed $85 \%$ were observed performing a type of manipulation and/or cervical technique, showing positive results such as decrease of pain and proper posture at the time of intervention to the end of the study. In $40 \%$ of subjects analyzed were seen that cervical joint manipulation in a single session revealed significant positive differences in flexion and extension. In $48.9 \%$ of the participants in the studies showed pain reduction in primary care and about 
$75 \%$ had reductions in 6 months. It was seen in the studies that $85.71 \%$ had the presence of high intensity pain at the initial moment of the research, taking into consideration the improvement in pain during the sessions.

Of the observed articles, various manipulations were performed such as: Positional Release Therapy (PRT), Osteopathic Manipulation (OM), osteopathic manipulation with cervical rhythmic articulatory technique, low-amplitude impulse techniques applied to the cervical spine, these manipulations and techniques have significant results for decrease in pain, resulting in the improvement of the posture, cervical and head positioning of the evaluated.

It was observed that $92.8 \%$ of subjects treated with cervical manipulation along with another technique presented with considerable satisfaction, i.e., the combination of manipulation of the cervical spine and exercises techniques resulted in significant improvement in the pain and disability compared with those treated only with manipulation or a type of technique.

\section{DISCUSSION}

In this systematic review, it was found that the joint manipulation promotes positive results such as reducing pain, range of motion and quality of life in patients with mechanical cervicalgia. ${ }^{(23)}$ The method of study of the manipulation has provided more detailed critically on this techniques, setting it to one of the best indications of treatment for mechanical neck pain. ${ }^{(24)}$

It may be emphasized that all articles included in this study were considered of good methodological quality according to the PEDro scale thus underlining the importance of the quality of clinical studies used to perform this review. Lacerda et al (2011), highlighted the importance of this quality in evidence-based medicine because it contributes to search for more judicious practices, by meeting, recognition and critical analysis of the knowledge produced. ${ }^{(25)}$

The manipulation of the cervical after 4 to 6 treatment sessions, being highlighted the Gonstead techniques, high-speed low-amplitude (HVLA) and full-scanning promoted pain relief in patients with mechanical neck pain. Haavik et al (2012), demonstrated that manipulation may help treat pain through a mechanism which can contribute to changes that alter cortical plasticity influenced in motor control. (26)

In the study of Bronfort et al (2001), was showed that the manipulation technique associated with stretching and isometric strengthening obtained better result than utilized only the manipulation, during this study was observed that there was an improvement in disability and an increase in neck range of motion, showing that such combination therapy has more effective and lasting results leading to an improved quality of life. ${ }^{(27)}$

Cervical manipulation, besides relieving the pain, makes the patient return to daily activities, improving functional ability. The use of cervical manipulation for the treatment of mechanical neck pain, disability and increased range of motion, promotes positive results reducing the pain symptoms and increasing the amplitude neck movement. ${ }^{(28-29)}$

\section{CONCLUSION}

The joint manipulation proved a significant tool for the treatment of mechanical neck pain, minimizing pain symptoms and reestablishing the range of motion. However, further studies should be encouraged in order to improve the treatment of mechanical neck pain, because of the diversity of manipulative techniques.

\section{AUTHOR'S CONTRIBUTION}

JCMAT: Article writing; DNO and AVSM: Search strategy and analysis of articles; PXLG and FFUSJ: Experimental design, article writing.

\section{CONFLICTS OF INTEREST}

The authors declare that they have no conflicts of interest.

\section{REFERENCES}

1. Kapreli E, Vourazanis E, Billis E, Oldham JA, Strimpakos N. Respiratory dysfunction in chronic neck pain patients. A pilotstudy. Cephalalgia. 2009;29(7):701-10. https://doi:10.1111/j.1468-2982.2008.01787

2. Organización Mundial de laSalud (OMS). "Directrices Sobre Formación Básica e Inocuidaden Quiropráctica”. Ginebra: OMS; 2006.

3. Hoving JL, Twisk JW, Devillé WL, Windt D, Koes BW, Bouter LM, et al. Prognostic factors for neck pain in general practice. Pain. 2004;110(3):63945. http://www.ncbi.nlm.nih.gov/pubmed/15288404

4. Franco ML. Bloqueos diagnóstico-terapéuticos de carillas articulares cervicales. Rev SocEsp Dolor. 2009;16(2):116-21. http://scielo.isciii.es/ scielo.php?script=sci_arttext\&pid=S1134-80462009000200007

5. Strimpakos N. The assessment of the cervical spine. Part 1: Range of motion and proprioception.JBodywMovTher.2011;15(1):114-24. http:// www.ncbi.nlm.nih.gov/pubmed/21147427

6. J-P Dumas, AB Arsenault, G Boudreau, E Magnoux, Y Lepage, A Bellavance, et al. Physical impairments in cervicogenic headache: traumatic vs. nontraumatic onset. Cephalalgia. 2001;21(9):884-93. http:// www.ncbi.nlm.nih.gov/pubmed/11903282

7. Buckle PW, Devereux JJ. The nature of work-related neck and upper limb musculoskeletal disorders. ApplErgon. 2002;33(3):207-17. doi:10.1016/ S0003-6870(02)00014-5

8. Kraychete DC, Sakata RK, Tanajura D, Guimarães AC, Angelim M. Perfi I clínico de pacientes com dor crônica do ambulatório de dor do Hospital Universitário Professor Edgard Santos - UFBA. Rev Baiana Saúde Pública. 2003;27:185-95.

9. Gabriel MRS, Petit JD, Carril MLS. Fisioterapia em traumatologia, ortopedia e reumatologia. Rio de Janeiro: Revinter; 2001.

10. Herbert S, Xavier R, Barros Filho TEP. Ortopedia e traumatologia: princípios e prática. Porto Alegre: Artmed. p.1376-87. 2003.

11. D’Ambrogio KJ, Roth GB. Terapia de liberação posicional: avaliação e tratamento da disfunção músculo esquelética. São Paulo: Manole; 2001.

12. Roberge RJ, Roberge MR. Overcoming barriers to the use of osteopathic manipulation techniques in the emergency department. West J Emerg Med. 2009;10(3):184-9. http://www.ncbi.nlm.nih.gov/pmc/articles/ PMC2729220/

13. Kamonseki DH, Fonseca CL, Souza TP, Zamunér AR, Peixoto BO, Chiao Yi L. Efeito imediato da manipulação thrust aplicada na coluna cervical alta 
sobre a abertura ativa da boca: ensaio clínico randomizado. J Health Sci Inst. 2012;30(3):277-80 277.

14. Barbosa AWC, Martins FLM, Barbosa MCSA, Vitorino DFM, Guimarães M, Renan P. Efeitos de curto prazo na dor, na atividade elétrica muscular e no posicionamento de cabeça da técnica full-scanning de manipulação vertebral em pacientes com desordens biomecânicas cervicais. Ter Man. 2012; 10(50):389-393.

15. Stelle R, Zeigelboim BS, Lange MC, Marques JM. Influência da manipulação osteopática na amplitude de rotação da coluna cervical em indivíduos com cervicalgia mecânica crônica. Rev Dor. São Paulo, 2013 outdez;14(4):284-9. http://dx.doi.org/10.1590/S1806-00132013000400010

16. Stelle R, Zeigelboim BS, Lange MC, Marques JM Influence of osteopathic manipulation on blood flow velocity of the cerebral circulation in chronic mechanical neck pain. Rev Dor. São Paulo, 2014 out-dez;15(4):281-6. http://dx.doi.org/10.5935/1806-0013.20140061

17. V. Maduro-de-Camargo, F. Alburquerque-Sendín, F. Bérzin, V. CobosStefanelli, C. Rodrigues-Pedroni, K. Santos. Immediate Effects of the Ashmore Manipulation Technique C5/C6, in Muscle Activity in patients with Mechanical Neck Pain. Eur J Ost Clin Rel Res. 2012;7(1):2-9. http:// bvsalud.org/portal/resource/pt/ibc-103592

18. Leaver AM, Maher CG, Herbert RD, Latimer J, McAuley JH, Jull G et al. A Randomized Controlled Trial Comparing Manipulation With Mobilization for Recent Onset Neck Pain. Arch Phys Med Rehabil September 2010. Vol 91. http://www.ncbi.nlm.nih.gov/pubmed/20801246

19. Vargas AC; Williams J. Inertial sensor real-time feedback enhances the learning of cervical spine manipulation: a prospective study. Medical Education 2014, 14:120. http://www.ncbi.nlm.nih.gov/ pubmed/24942483

20. Wontae Gong. Effects of Cervical Joint Manipulation on Joint Position Sense of Normal Adults. J. Phys. Ther. 2013. Sci. 25: 721-723. doi: 10.1589/ jpts. 25.721

21. Saavedra-Hernández $M$, Castro-Sánchez AM, Arroyo-Morales $M$, Cleland JA, Lara-Palomo IC, Fernández-de-Las-Peñas C. Short-Term Effects of Kinesio Taping Versus Cervical Thrust Manipulation in Patients With Mechanical Neck Pain: A Randomized Clinical Trial. journal of orthopaedic \& sports physical therapy. August 2012. 42(8). DOI: 10.2519/ jospt.2012.4086

22. Kolberg C, Horst A, Moraes MS, Duarte FC, Riffel AP, Scheid T, et al. Peripheral oxidative stress blood markers in patients with chronic back or neck pain treated with high-velocity, low-amplitude manipulation. Journal of Manipulative and Physiological Therapeutics HVLA Changes Antioxidant Activity February 2015. http://dx.doi.org/10.1016/j.jmpt.2014.11.003

23. Gross AR, Hoving JL, Haines $T A$, Goldsmith $\mathrm{CH}$, Kay T, Aker $\mathrm{P}$, et al. A Cochrane review of manipulation and mobilization for mechanical neck disorders.Spine. 2004;29:1541-8. http://doi: 10.1097/01. BRS.0000131218.35875.

24. Haavik $\mathrm{H}$, Murphy $\mathrm{B}$. The role of spinal manipulation in addressing disordered sensorimotorintegration and altered motor control. J ElectromyogrKinesiol. 2012. http://www.ncbi.nlm.nih.gov/ pubmed/22483612

25. Lacerda RA, Nunes BK, Batista AO, Egly EY, Graziano KU, Angelo M, et al. "Práticas baseadas em evidências publicadas no Brasil: identificação e análise de suas vertentes e abordagens metodológicas." Rev Esc Enferm USP. 2011;45(3):777-86. http://dx.doi.org/10.1590/S008062342011000300033

26. Haavik-Taylor H, Murphy B. Cervical spine manipulation alters sensorimotor integration: a somatosensory evoked potential study. ClinNeurophysiol. 2007;118(2):391-402. doi:10.1016/j.clinph.2006.09.014

27. Bronfort G, Evans R, Nelson B, Aker PD, Goldsmith CH, Vernon H. A randomized clinical trial of exercise and spinal manipulation for patients with chronic neck pain.Spine 2001;26:788-97. http://www.ncbi.nIm.nih. gov/pubmed/11295901

28. Vernon $\mathrm{H}$, Humphreys BK. Chronic mechanical neck pain in adults treated by manual therapy: a systematic review of change scores in randomized controlled trials of a single session.JManManipTher.2008;16(2):E42-E52. http://www.ncbi.nlm.nih.gov/pmc/articles/PMC2565115

29. Tseng YL, Wang WT, Chen WY, Hou TJ, Chen TC, Lieu FK. Predictors for the immediate responders to cervical manipulation in patients with neck pain.Man Ther. 2006;11(4):306-15. http://www.ncbi.nlm.nih.gov/ pubmed/16380287 